\title{
Lead concentration in soil inside the area of former battery production factory, Berat, Albania
}

\begin{abstract}
Lead is a trace element in the earth's crust, but it is not essential element. Lead poisoning is an important environmental pollutant that can have life-long adverse health effects. Lead is widely used in industry for building construction, lead-acid batteries, bullets, shot, etc. The current study reports the determination of lead concentration in surface and profile soil samples, inside the territory of former Factory Production of Batteries, Uznove, Berat, Albania. We have collected a total of 10 soil samples. The representative soil samples were analyzed using atomic absorption spectrometry for their lead content. The concentration of lead in soil samples are compared with the Maximum Contaminant Levels (MCL) specified by the Directive 86/278/EEC. Also, from results obtained we have calculated Hazardous Quoted (HQ). HQ in representative surface soil samples was 3.78-18.88 times higher than normal value. Concentration of lead in profile of soils tends to decrease. The level of lead in the profile soil samples, in the depth of $80-90 \mathrm{~cm}$ has decreased about 2-50 times compared to the concentration of lead in surface soil samples.
\end{abstract}

Keywords: lead, surface and profile soil samples, Atomic Absorption Spectrometry (AAS).

\section{INTRODUCTION}

The rapid development of technology and their extension in the different fields of life in addition to primary production have caused the continuous emission of waste in the surroundings, thus resulting in negative impacts on ecosystem and human health. Among other things, heavy metals, especially lead, have become impurities, serious environmental pollutions over the last decades.

Lead is known as one of the most toxic heavy metals in the environment [1]. The sources of emission of lead in the environment are natural and anthropogenic [2]. Over the years lead is extracted from the mines for different purposes, such as: production of batteries, half-done production of metallic sheets and pipes, alloys, additive in benzene, in PVC, in ammunitions [3]. Since lead is mostly used for the production of batteries, the major pollution comes exactly from this industry.

In general, areas close to Factory of Battery Production are presented with environmental problems, due to increased production and consumption of lead from vegetation and livestock. As a result, the contamination of soils has influence on the increase of the level of lead in vegetation [4]. Lead is a continuous pollutant in the environment due to the fact that it is not degraded or destroyed [5]. The exposure to lead in the environment results in a wide range of negative effects, biochemical and toxic effects, depending from the level of lead

Author address: Institute of Applied Nuclear Physics, University of Tirana, Albania

Paper received: 16. 12. 2014.

Paper accepted: 09. 02. 2015. and time of extended. The high level of lead reaches the food chain through the supply of drinking water, respiration and food consumption. The presence of lead and other heavy metals is dangerous because they have tendency to bioaccumulate [6]. The environmental protection should be and remain the main goal and task of the society.

The purpose of this study is: Assessment of the environmental and impact of the industrial lead waste in the territory of the ex-Factory of Battery Production, Berat, Albania according to the dispersal of lead on the surface of soil and Verification of the penetration of lead in the depth of soil. The complex of Factory for the production of batteries in Berat, Albania has begun its activity in 1970. It was designed not only to produce batteries for passengers' cars and trucks, but also other military and technical equipment. This factory has operated at full capacity until 1997, whereas the partial work continued up to April 2008. During that period the number of employees amounted to 600 700. The main processes of work in the course of the activity of the factory were: The opening process; smelting and filling the batteries, which constitute the main sources of pollution from the factory. There was an also a unit within the factory, which was used for recycling old batteries. It was used also to separate used lead, which was used later on as secondary contribution in the raw material in the primary process.

One of the methods for determination of the total contents of heavy metals of their environmental concentrations is Atomic Absorption Spe- 
ctroscopy (AAS).The level of $\mathrm{Pb}$ in soil samples was compared to the values recommended by the European Community according to Directive 86/278 EEC[7] and was calculated the potential of risk Hazardous Quoted (HQ) by USEPA.

\section{MATERIAL AND METHOD}

Both representative soil samples depth and area were collected within the area of the former Battery Production Factory, Berat, Albania. This Factory is located in the northeastern city of Berat, with respective coordinate: $40^{\circ} 42^{\prime} 24.82^{\prime \prime} \mathrm{N}$ and $19^{0} 58^{\prime} 59.42$ " E. During the sampling we have chosen four stations within the area of Factory and we have collected a total 10 samples. Four samples representing are collected at the surface soil $(0-5 \mathrm{~cm})$ for each sampling point. Six samples representing in the three sampling points are taken in profile of soils in to the depth about of $90 \mathrm{~cm}$.

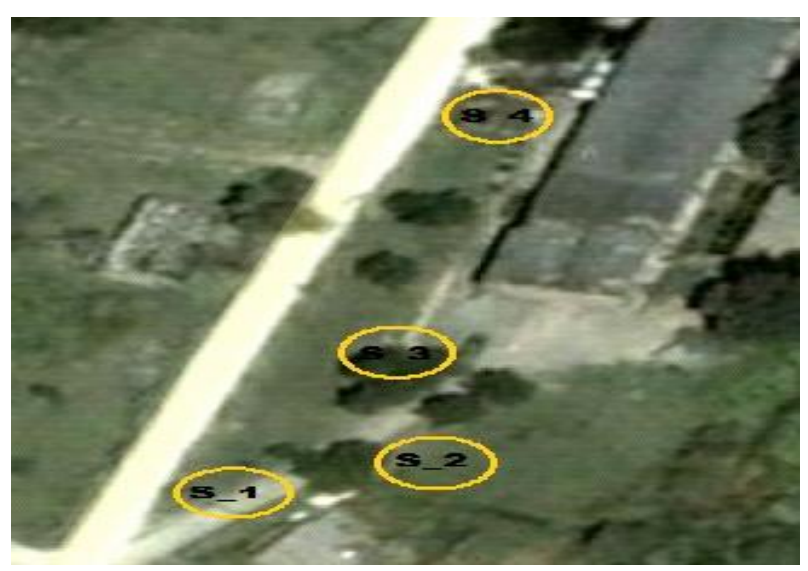

Figure 1 - Map of sampling stations of soil.
These sampling stations and their coordinate are presented respectively in table 1 and in figure 1. Represented soil samples analyzed using Atomic Absorption Spectrometer, Aanalyst 800 Perkin Elmer with Atomic Absorption Spectrometry, Flame method [8] (Perkin-Elmer Corp. 1991-1999). Hollow cathode lamp used as radiation source for the determination of lead according recommended conditions. Acids used for the digestion of samples, stock solutions of lead have high grade purity. Representative soil samples are digested according Analytic Method Atomic Absorption Spectrometry. Digestion soil samples are prepared using a procedure recommended by Environmental Protection Agency [9] was used as the conventional acid extraction method. Instrumental conditions for lead are based on Analytical Methods of Atomic Absorption Spectrometry, from Perkin Elmer [8]. Three applications were carried out for the measurement of calibration standards and measurement of samples. For each element calibration curve equation is linear and passing through point zero. A quality control material (IAEA_Soil_7) was analyzed in parallel with the soil samples.

\section{RESULTS AND DISCUSSIONS}

We have collected a total 10 soil samples during the sampling, whereas 4 samples are taken at the area and 6 samples are taken in the depth of soil (profile soil). In the table 2 is presented mean concentration of lead as well as Relative Standard Deviation percentage (\% RSD) and Standard Deviation (SD) in representative soil samples of the territory of the former Battery Production Factory.

Table 1 - Concentration of $\mathrm{Pb}$, both area and depth soil samples, within territory of Factory.

\begin{tabular}{|c|c|c|c|c|c|c|c|}
\hline & \multicolumn{7}{|c|}{ Coordinates } \\
\hline $\mathrm{Nr}$ & Sampling stations & $\begin{array}{l}\text { Code in } \\
\text { AAS }\end{array}$ & Nord & East & $\begin{array}{c}\mathrm{Pb} \\
(\mathrm{mg} / \mathrm{kg})\end{array}$ & SD & RSD \% \\
\hline 1 & S_1_Surface soil $(0-5 \mathrm{~cm})$ & $\mathrm{P} 1 \_\mathrm{T} 1$ & $40^{\circ} 42^{\prime \prime 21.32 '}$ & $19^{0} 58^{\prime \prime} 56.74$ & 3008 & 33,09 & 1,10 \\
\hline 2 & S_1_Profile soil $(10-15 \mathrm{~cm})$ & P1_T2 & $40^{\circ} 42^{\prime \prime 21.32}$ & $19^{0} 58^{\prime \prime} 56.74^{\prime}$ & 3052 & 82,41 & 2,70 \\
\hline 3 & S_2_Surface soil $(0-5 \mathrm{~cm})$ & P2_T1 & $40^{\circ} 42^{\prime \prime 21.61}$ & $19^{0} 58^{\prime \prime} 57.63^{\prime}$ & 5663 & 7,360 & 0,13 \\
\hline 4 & S_2_Profile soil $(10-15 \mathrm{~cm})$ & P2_T2 & $40^{\circ} 42^{\prime \prime 2} 21.61^{\prime}$ & $19^{0} 58^{\prime \prime} 57.63^{\prime}$ & 4789 & 76,62 & 1,60 \\
\hline 5 & S_2_Profile soil $(20-30 \mathrm{~cm})$ & P2_T3 & $40^{\circ} 42^{\prime \prime 21.61}$ & $19^{0} 58^{\prime \prime} 57.63^{\prime}$ & 4741 & 37,93 & 0,80 \\
\hline 6 & S_3_Surface soil $(0-5 \mathrm{~cm})$ & P3_T1 & $40^{\circ} 42^{\prime \prime 22.40^{\prime}}$ & $19^{0} 58^{\prime \prime} 57.68^{\prime}$ & 1135 & 41,98 & 3,70 \\
\hline 7 & S_4_Surface soil $(0-5 \mathrm{~cm})$ & P4_T1 & $40^{\circ} 42^{\prime \prime 24.18^{\prime}}$ & $19^{0} 58^{\prime \prime} 58.011^{\prime}$ & 5511 & 22,04 & 0,40 \\
\hline 8 & S_4_Profile soil $(10-15 \mathrm{~cm})$ & P4_T2 & $40^{\circ} 42^{\prime \prime 24.18^{\prime}}$ & $19^{0} 58^{\prime \prime} 58.01^{\prime}$ & 821 & 15,59 & 1,90 \\
\hline 9 & S_4_Profile soil $(30-40 \mathrm{~cm})$ & P4_T3 & $40^{\circ} 42^{\prime \prime 24.18^{\prime}}$ & $19^{0} 58 " 58.011^{\prime}$ & 196 & 7,250 & 3,70 \\
\hline 10 & S_4_Profile soil $(60-80 \mathrm{~cm})$ & P4_T4 & $40^{\circ} 42^{\prime \prime 24.18^{\prime}}$ & $19^{0} 58 " 58.011^{\prime}$ & 135 & 3,780 & 2,80 \\
\hline
\end{tabular}


A graph in figure 2 is presented the concentration of lead respectively at area and depth of representative soil samples. While graph 3 is presented counter plot of $\mathrm{Pb}$ in $\mathrm{mg} / \mathrm{kg}$ in surface soil versus coordinate of soil samples.

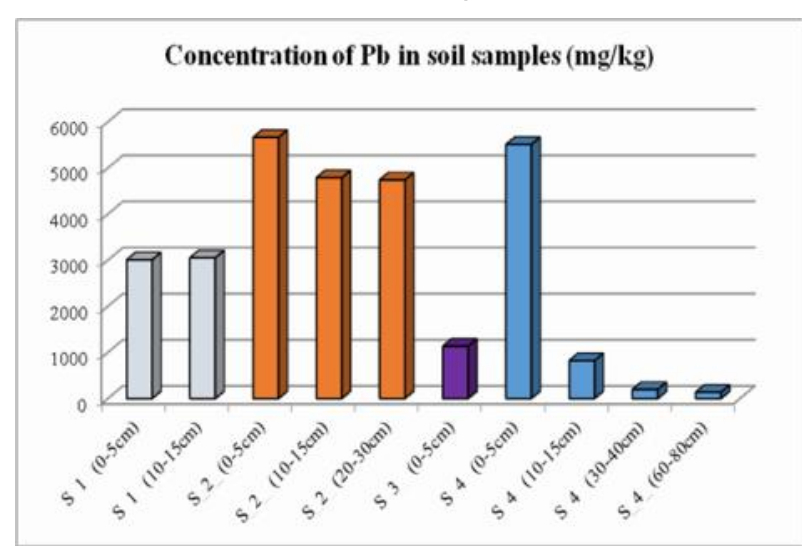

Figure 2 - Variation of lead in soil samples

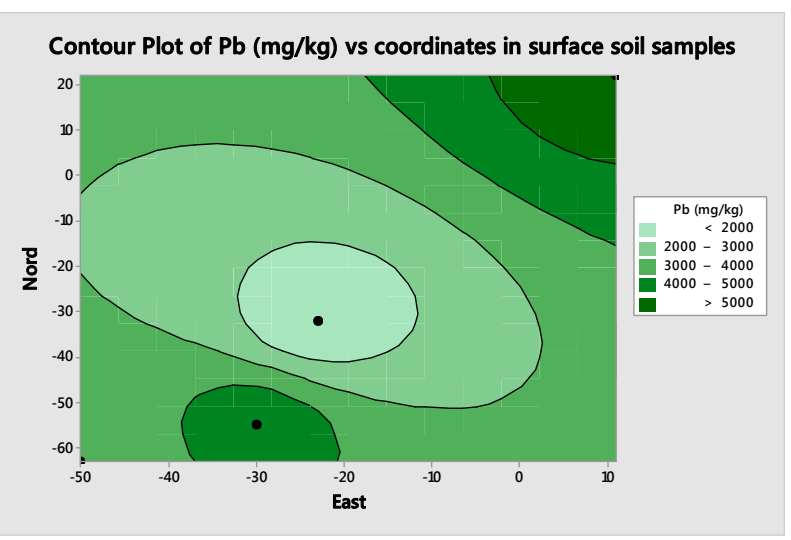

Figure 3 - Counter plot of $\mathrm{Pb}$ vs coordinates

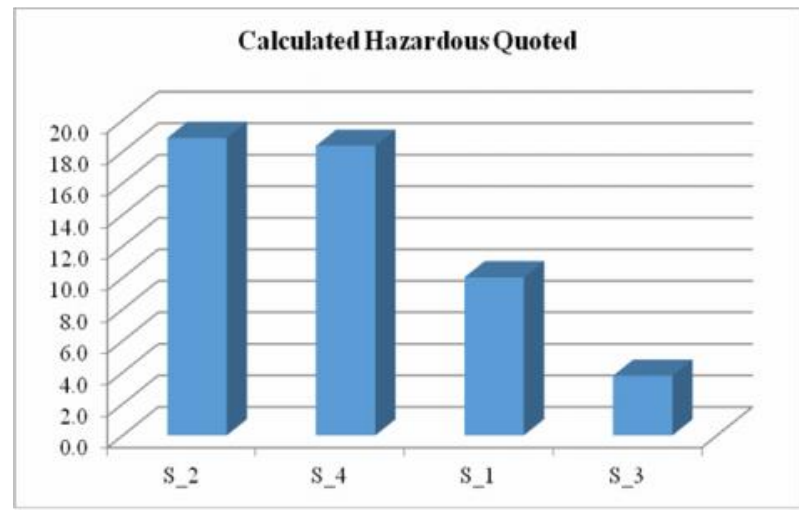

Figure 4 - Variation of $H Q$ in surface soil

From results obtained observed the mean concentration of lead in representative surface soil samples were very high. The mean concentration of lead in surface samples was found in the order $1135 \mathrm{mg} / \mathrm{kg}-5563 \mathrm{mg} / \mathrm{kg}$. During the sampling in the territory of Factory, in the points S_1, S_2 and S_4 we are collected 6 soil samples in the different depth. From results obtained in representative profile soil samples observed that the concentration of lead from the surface in depth of soil tends to decrease. The mean concentrations level of lead in soil samples are compared with the Maximum Contaminant Levels (MCL) specified by the Directive $86 / 278 / E E C$. MCL of lead in soil recommended by the Directive $86 / 278 / \mathrm{EEC}$ is $50-300(\mathrm{mg} / \mathrm{kg} \mathrm{dm})$. In addition from results obtained we have calculated Hazardous Quoted [10]. In figure 4 shows the variation of $H Q$ in surface soil samples. The factor of calculated Hazardous Quoted, HQ in representative soil samples was found in the order 3.7818.88 times higher than normal.

Hazardous Quoted for surface soil samples is higher than 1 , which means this territory is contaminated and this pollution is associated with the high negative ecological and human effects

\section{CONCLUSION}

The lead was found to be present in high concentration in all of the surface soil samples analyzed.

The average of calculated Hazardous Quoted, is 12.8 times higher than 1 .

From the results obtained all the surface soil samples analyzed contained lead concentration above the MCL, recommended by Directive 86/278/EEC for lead in soil.

Concentration of lead in profile of soils tends to decrease.

The level of lead in the profile soil samples, in the depth of $80-90 \mathrm{~cm}$ (S_4), has decreased about 2-50 times compared to the concentration of lead in surface soil samples.

In addition, the fraction of lead has penetration in to the profile of soil (in the depth $40-50 \mathrm{~cm}$ ).

During this investigation the level of fraction of lead in surface soil samples is very high. The area of the former Battery Production Factory, Berat, Albania, presented an area contaminated with high concentration of lead.

\section{REFERENCES}

[1] Alushllari M. \& Civici N. (2014). Assessment of lead accumulation by leaves Cynadon dactiyon and needles of Pinus pinea. Physical chemistry 2014, proceedings vol. 2. Pg 534-537.

[2] Carpenter SR, Caraco NF, Correll DL, Howarth RW, Sharpely AN, Smith VH, (1998) Nonpoint Pollution of surface waters with phosphorus and nitrogen, Ecological Applications. 8, 559-568.

[3] Demayo, A., M.C. Taylor, K.W. Taylor, and P.V. Hodson. 1982. Toxic effects of lead and lead compounds on human health, aquatic life, wildlife plants, and livestock. Critical Reviews in Environmental Control, 12, 257-305. 
[4] Zakrzewski SF (2002). Environmental Toxicology. Third Edition. Oxford University Press. USA, pp.545.

[5] Ernst WHO (1996). Bioavailability of Heavy Metals and Decontamination of Soils by Plants. Applied Geochemistry 11: 163-167.

[6] Censiat P, Spoto SE, Saiano F, Sprovieri M, Mazzola S, Nardone G, Di Geronimo SI, Punturo R, Ottonello D, (2006) Heavy metals in coastal water system. Chemosphere 64,1167-1176.

[7] EEC, Economic European Communities. (2006). The Council Directive $86 / 278 /$ EEC on protection of the environment.
[8] (Perkin-Elmer Corp. 1991-1999). Perkin-Elmer Corp.: 1964-2000, Analytical Methods for Atomic Absorption Spectrophotometry.

[9] Anonymous, EPA,Method 3050B. http://www.epa. gov/osw/hazard/testmethods/sw846/pdfs/3050b.pdf

[10] U.S. EPA. (Environmental Protection Agency). 2006. Risk Assessment Guidance for Superfund Volume I: Human Health Evaluation Manual (Part E, Supplemental Guidance for Dermal Risk Assessment), Final. EPA/540/R/99/005. Office of Solid Waste and Emergency Response, Washington, DC. PB99-963312.

\section{IZVOD}

\section{ISPITIVANJE KONCENTRACIJE OLOVA U ZEMLJIŠTU U KRUGU BIVSE FABRIKE ZA PROIZVODNJU BATERIJA}

Olovo je element u tragovima u zemljinoj kori, ali nije bitan elemenat. Olovo je važan zagađivač životne sredine, koji može imati trajne štetne posledice po zdravlje. Olovo ima široku primenu $u$ industriji za izgradnju objekata, olovnih baterija, itd. Izvršena su određivanja koncentracije olova u površinskim $i$ profil zemljištu uzoraka, unutar teritorije bivše fabrike za proizvodnju baterija, Uznove, Berat, Albanija.

Uzeto je ukupno 10 uzoraka zemljišta. Reprezentativni uzorci zemljišta su analizirani korišćenjem atomske apsorpcione spektrometrije na olovo. Koncentracije olova u uzorcima zemljišta su u poređenju sa maksimalnim nivoima zagađenosti vazduha (MCL) utvrđeni Direktivom 86/278 / EEC. Takođe, za dobijene rezultate izračunati su indeksi $H Q$. HQ indeks u površinskim uzorcima tla je 3.78-18.88 puta veći od normalne vrednosti. Koncentracija olova u profilu zemljišta ima tendenciju da se smanjuje. Koncentracija olova u uzorcima zemljišta u profilu, u dubini od 80-90 cm je smanjena za 2-50 puta u odnosu na koncentracije olova u površinskim uzorcima zemljišta.

Ključne reči: olovo, površina i profil tla, zagađenje sredine, atomska apsorpciona spektrometrija (AAS).

Originalni naučni rad

Rad primljen: 16.12.2014.

Rad prihvaćen: 09.02.2015. 